\title{
NEITHER FISH NOR FOWL: ADMINISTRATIVE JUDGES IN THE MODERN ADMINISTRATIVE STATE
}

\section{Russell L. Weaver* Linda D. Jellum**}

This article examines the role of administrative adjudication in the United States constitutional system. It begins by noting that such adjudication fits uncomfortably within a system of divided powers. Administrative judges, including administrative law judges $[A L J s]$ (who have the highest level of protection and status), are considerably more circumscribed than ordinary Article III judges. Indeed, administrative judges are usually boused in the agencies for which they decide cases, rather than in independent adjudicative bodies, and they do not always have the final say regarding the cases they decide. In many instances, the agency can appeal an adverse administrative judge's decision directly to the head of the agency, and the agency head retains broad power to overrule the administrative judge's determinations. In other words, the agency can substitute its judgment for that of the administrative judge regarding factual determinations, legal determinations, and policy choices. As a result, many administrative adjudicative structures involve difficult tradeoffs between independence, political control, and accountability. This article examines issues related to the status and power of administrative judges, as well as the constraints that have been imposed on administrative adjudicative authority, and explores whether those constraints continue to serve the purposes for which they were originally imposed.

Cet article examine le rôle du règlement de différends dans le domaine administratif dans le cadre du système constitutionnel des États-Unis. Il note d'abord qu'une telle façon de régler les différends cadre difficilement avec un système où les pouvoirs sont divisés. Les juges administratifs, y inclus les juges de droit administratif (qui jouissent du niveau le plus élevé de protection et de statut), sont considérablement plus restreints que les juges ordinaires sous l'Article III. En effet, les juges administratifs sont d'habitude logés dans les agences pour lesquelles ils décident les cas, plutôt qu'au sein d'organismes indépendants de règlement de différends, et ils n'ont pas toujours le dernier mot dans les cas qu'ils jugent. Dans bien des cas, l'agence peut porter en appel directement au chef de l'agence une décision défavorable d'un juge administratif, et le chef de l'agence possède de vastes pouvoirs pour annuler la décision du juge administratif. En d'autres mots, l'agence peut substituer son jugement à celui du juge administratif quant aux décisions de fait, aux décisions de droit et

* Professor of Law \& Distinguished University Scholar, University of Louisville, Louis D. Brandeis School of Law. This paper was originally written for and presented at the Sixth Administrative Law Discussion Forum, Québec City, May 25-26, 2010. The authors wish to thank the forum participants for their comments, and especially to thank Professor Michael Asimow and Professor Jeffrey Lubbers.

** Professor of Law, Mercer University School of Law. We would both like to thank Troy Clark J.D. expected Mercer Law School 2010) for his help researching this article. 
aux choix de politiques. Par conséquent, plusieurs structures de règlement de différends dans le domaine administratif comportent des compromis difficiles entre l'indépendance, le contrôle politique et l'obligation de rendre compte. Cet article examine des questions se rapportant au statut et an pouvoir de juges administratifs, ainsi qu'aux contraintes qui ont été imposées sur l'autorité de régler des différends dans le domaine administratif, et explore la question à savoir si ces contraintes continuent à servir les buts pour lesquels elles ont été imposées originellement.

\section{INTRODUCTION}

Administrative adjudication has always rested uncomfortably in the United States constitutional system. In theory, if not entirely in practice, the system includes separation of powers principles, as well as the concept of checks and balances, throughout the constitutional structure.' For example, the Constitution vests legislative power in Congress, ${ }^{2}$ judicial power in the courts ${ }^{3}$ and executive power in the President. ${ }^{4}$ However, the lines of separation between the branches are not complete; and, there are many instances when power is divided between two branches of government. For example, not only must both houses of Congress pass legislation, it must be presented to the President for signature or veto. ${ }^{5}$

Modern administrative agencies present significant challenges to the notion of separated powers because they frequently perform many functions committed to coordinate branches of government. For example, many agencies "legislate" (in the sense of creating rules and regulations that can have the force and effect of legislative enactments), "adjudicate" (in the sense of deciding cases), and "administer" (in the sense of executing and administering the laws). 'Additionally, although most administrative agencies reside in the executive branch of government, Congress has limited the President's authority to remove the heads of some agencies and other executive officials, ${ }^{8}$ and thereby allowed those agencies to function relatively independently of presidential authority.

$1 \quad$ Political philosophers whose ideas influenced the writing of the United States Constitution include (but are hardly limited to) Montesquieu and Locke. See Baron de Montesquieu, The Spirit of Laws, David Wallace Carrithers ed translated by Thomas Nugent, (London: Nourse, 1750; Berkeley: University of California Press, 1977) at 202. "When the legislative and executive powers are united in the same person, or in the same body of magistracy, there can then be no liberty...."); John Locke, Two Treatises of Government, Peter Laslett, ed, 2d ed. (London: Cambridge University Press, 1690, 1970) at 380. ("the legislative cannot transfer the power of making laws to any other hands; for it being but a delegated power from the people, they who have it cannot pass it over to others.").

2 U.S. Const. art. I, $\$ 1$ ("[a]ll legislative Powers ... shall be vested in a Congress of the United States...").

3 U.S. Const. art. III, $\int 1$ (" $[t]$ he judicial Power of the United States, shall be vested in one Supreme Court, and in such inferior Courts as the Congress may from time to time ordain and establish.”) The framers founded an independent judiciary to rectify the mistake of the English Constitution, which made its judiciary subject to the control and pressures of Parliament. Irving R. Kaufman, "The Essence of Judicial Independence" (1980) 80 Colum L Rev 671 at 672-87.

4 U.S. Const. art II, $\int 1$ (" $[\mathrm{t}]$ he executive Power shall be vested in a President of the United States of America.’).

$5 \quad$ U.S. Const. art. 15 7.

6 See William F. Funk, Sidney A. Shapiro \& Russell L. Weaver, Administrative Practice and Procedure: Problems and Cases, 4th ed, (St. Paul, MN: West Publishing Company, 2010) at 517.

$7 \quad$ Ibid. See also Commodity Futures Trading Commission v. Schor, 478 U.S. 833 (1986).

8 See Humphrey's Executor v. United States, 295 U.S. 602 (1935). 
One peculiarity of the U.S. administrative system is the fact that many agencies are allowed to hear and adjudicate cases. Article III of the United States Constitution vests judicial power in the federal courts' and provides Article III judges with lifetime tenure and substantial independence from the other two branches of government. Under the Constitution, Article III courts exercise broad power to "say what the law is" ${ }^{\prime \prime 10}$ and have sometimes rendered sweeping decisions that have reshaped society." If Congress wishes to override an Article III court's decision, Congress may have no choice but to try and amend the Constitution (a process that rarely succeeds).

Administrative courts and adjudicative structures ${ }^{12}$ function much differently. ${ }^{13}$ In contrast to Article III judges, the powers of administrative judges, including administrative law judges [ALJs] (who have the highest level of protection and status), ${ }^{14}$ are considerably more circumscribed. Administrative judges are usually housed in the agencies for which they decide cases, ${ }^{15}$ rather than in independent adjudicative bodies. ${ }^{16}$ In addition, administrative judges do not always have the final say regarding the cases they decide. In many instances, the agency can appeal an

9 U.S. Const. art. III.

10 See Marbury v. Madison, 5 U.S. 137 (1803).

11 See Roe v. Wade, 410 U.S. 113 (1973); Brown v. Board of Education, 349 U.S. 294 (1955).

12 In the federal system, an adjudicative body can now be classified as an Article I, Article II, Article III, or Article IV court, in reference to the article of the Constitution from which the court's authority stems. Article I courts are typically legislative courts. Some examples include the Social Security Administration's Office of Disability Adjudication and Review and the United States Court of Appeals for Veterans Claims. There are many others. Article II courts are generally established under the President's authority pursuant as Commander in Chief to maintain order and justice in military occupied territories and insular possessions. Some examples include Guantanamo military commission and High Court of American Samoa. The Article III courts include the Supreme Court of the United States and the inferior courts established by the Congress pursuant to its Article III powers. U.S. Const. art. III, $\$ 1$. There are currently thirteen courts of appeals, ninety-four district courts, and the U.S. Court of International Trade. Article IV courts are tribunals established in territories of the United States by the Congress, pursuant to the Territorial Clause. A few examples of the Article IV courts that still exist include the United States District Court for the Northern Mariana Islands, the District Court of Guam, and the District Court of the Virgin Islands.

13 Commentators have long discussed the lack of independence in this area. For just a few examples, see Ron Beal, "The Texas State Office of Administrative Hearings: Establishing Independent Adjudicators in Contested Case Proceedings While Preserving the Power of Institutional DecisionMaking" (2005) 25 Journal of the National Association of Administrative Law Judges 119; James F. Flanagan, "Redefining the Role of the State Administrative Law Judge: Central Panels and Their Impact on State ALJ Authority and Standards of Agency Review" (2002) 54 Admin L Rev 1355 at 1382-85; Richard B. Hoffman \& Frank P. Cihlar, "Judicial Independence: Can It Be Without Article III?” (1995) 46 Mercer L. Rev. 863; Harold J. Krent \& Lindsay DuVall, “Accommodating ALJ Decision Making Independence with Institutional Interests of the Administrative Judiciary" (2005) 25 Journal of the National Association of Administrative Law Judges 1; L. Hope O'Keeffe,

"Administrative Law Judges, Performance Evaluation, and Production Standards: Judicial Independence Versus Employee Accountability”, Note, (1986) 54 Geo Wash L Rev 591.

14 See 5 U.S.C. $\$ 7521$ (2009); 5 C.F.R. $\$ 1201.131$ (2007).

15 Administrative adjudicators have existed in the United States since the earliest times. See Louis G. Caldwell, "A Federal Administrative Court" (1936) 84 U Pa L Rev 966 at 970 ("[U]nder a bewildering medley of federal statutes, judicial functions galore have been lodged in the President, in agencies directly responsible to the President, in the heads of government departments, in subordinate officials and bureaus in those departments, and in the so-called independent boards and commissions...."). As early as 1936, there were "about seventy-three administrative tribunals in the federal government performing judicial functions in about 267 classes of cases." Ibid at 970.

16 See Russell L. Weaver, "Management of ALJ Offices in Executive Departments and Agencies" (1995) 47 Admin L Rev 303 ["Management of ALJ Offices"]. 
adverse administrative judge's decision directly to the head of the agency. ${ }^{17}$ If the decision is not appealed, it becomes the "decision of the agency." ${ }^{18}$ Yet, if appealed, the agency retains broad power to overrule the administrative judge's determinations under the Administrative Procedure Act [APA]: "On appeal from or review of the initial decision, the agency has all the powers which it would have [had] in making the initial decision...."19 In other words, the agency can substitute its judgment for that of the administrative judge regarding factual determinations, ${ }^{20}$ legal determinations, and policy choices.

As a result, many administrative adjudicative structures involve difficult trade-offs between independence, political control, and accountability. Most administrative judges function as employees of the agencies for which they decide cases. If independence is truly a core attribute of the American style of judging and if administrative judges are not truly independent, then administrative judges may be more accurately characterized as administrative functionaries with judge-like duties than as true judges. ${ }^{21}$

In this article, we examine issues related to the status and power of administrative judges. We begin by examining the history and development of existing administrative structures and the current status of the law. From there, we explain the constraints that have been imposed on administrative adjudicative authority and explore whether those constraints continue to serve the purposes for which they were originally imposed. We then examine some of the ideas that have been floated regarding how administrative judges (including ALJs) could be restructured and governed. None of these ideas is entirely satisfactory. However, given that the status quo is not entirely satisfactory either, it is worthwhile to re-examine some of these ideas and to explore some new ones.

\section{EVOLUTION OF THE MODERN ADJUDICATIVE STRUCTURE}

Even though the modern administrative adjudicative system is imperfect, it is a vast improvement over the system that preceded it. At the beginning of the nineteenth century, most adjudications were presided over by "examiners" who were appointed by the agencies themselves. ${ }^{23}$ These examiners were hardly independent, holding the status of "underling" or "subordinate" in the sense that the agencies for which they worked controlled their assignments, their compensation, their promotions, and their retention. ${ }^{25}$ Indeed, some early examiners served completely at the pleasure of their

175 U.S.C. $\int 557$ (b). Of course, the reason for allowing appeals to the agency is that the agency is empowered to make law through adjudication.

Ibid.

Ibid.

20 Agencies are somewhat limited in rejected ALJ findings of fact based on testimonial evidence. Penasquitos Village v. Nat. Labor Relations Bd., 565 F.2d 1074 (9th Cir. 1977).

21 James E. Moliterno, “The Administrative Judiciary's Independence Myth" (2006) 41 Wake Forest L Rev 1191 at 1197.

22 The term "examiners" came into use in 1906. 3 Kenneth Culp Davis, Administrative Law Treatise 2d ed. (San Diego: K. C. Davis Pub. Co., 1980) \$17.11, at 313.

23 See Management of ALJ Offices, supra note 16, at 303.

24 See Malcolm Rich, “Adapting the Central Panel System: A Study of Seven States” (1981) 65 Judicature 246 at 246 ("The agencies controlled the compensation and job tenure of their hearing officers and could ignore their decisions and enter de novo rulings instead.").

25 Ibid at 303-04. 
superiors and had no job security whatsoever. ${ }^{26}$ Hence, judicial "independence" and "impartiality" were not an assured part of the administrative equation.

By the 1930s, commentators began to raise serious concerns regarding the status of hearing examiners, as well as about their ability to decide cases fairly, independently, and impartially. ${ }^{27}$ In a 1934 report, the American Bar Association's [ABA] Special Committee on Administrative Law criticized the fact that some examiners exercised both prosecutorial and adjudicative functions. ${ }^{28}$ One member of the Committee summed up the concerns as follows:

If there is anything of which we can be relatively sure after some hundreds, even thousands, of years of experience with judicial machinery, it is that no man can be trusted to be judge in his own case. And he is a judge in his own case if he is also the prosecutor or if he is also the legislator who made the rule he is asked to interpret and apply. Agency after agency in our federal government is authorized to wield all three powers of government at once. Wearing its legislative toga, a commission makes a regulation, on compliance with which John Doe's right to continue in business may depend. Having reason to believe that John Doe is guilty of violating the regulation, the commission doffs the toga and, taking up the executive sceptre, investigates and prosecutes him. With the sceptre still in its hand, the commission hurriedly dons the judicial ermine and proceeds to present itself at least two scintillas of evidence to prove that it was right in the first place. While care is sometimes taken to preserve the form of placing the burden of proof on the prosecutor, all the form in the world cannot disguise the fact that the burden is usually on John Doe to prove himself innocent before a commission that at least strongly suspects he is guilty. If John or his lawyer construes the regulation differently than does the commission, that is just unfortunate for John. The commission made the regulation and is confident that it knows just what it meant to say. And it is always free to change its mind. John is in the position of a man whose wife changes her system of bidding in the middle of a bridge game without notice. He is sure to lose and is equally sure to get blamed for it. ${ }^{29}$

\footnotetext{
26 Ibid.

27 An ABA Report concluded that appointments to administrative tribunals are all too generally classed as patronage and, it is to be feared, the decisions of some of them are occasionally dealt with as a form of patronage. It is not easy to maintain judicial independence or high standards of judicial conduct when a political sword of Damocles continually threatens the judge's source of livelihood. While a few federal administrative tribunals have, in spite of all obstacles, preserved a high degree of independence from political pressure and political considerations, unfortunately there are others which have yielded and as a result the cause of justice has suffered. Special Report of the Special Committee on Administrative Law, (1934) 59 American Bar Association 539 at 546 [ABA Special Report]; See also Jeffrey S. Lubbers, "Federal Administrative Law Judges: A Focus on Our Invisible Judiciary" (1981) 33 Admin L Rev 109 at 111.

28 ABA Special Report, ibid at 545-46.

29 Caldwell, supra note 15, at 973-74.
} 
Separation of functions and status were not the only concerns. Even had examiners been functionally separate from their agencies, their decisions were not final and could be overridden by agency superiors. ${ }^{30}$

During the debate, many suggestions were offered regarding how to reform the system. Some argued that Congress should create a federal administrative court that would hear only administrative cases. ${ }^{31}$ Others suggested that Congress should create an independent administrative judiciary, a central panel of judges, to adjudicative administrative matters. ${ }^{32}$ Congress ultimately rejected both of these suggestions. In 1946 , with the passage of the $A P A,{ }^{33}$ Congress opted for a third approach that was unique to administrative law, but included a number of protective components. First, Congress sought to prevent agency officials from acting as lawmaker, investigator, prosecutor, and jury in the same case. Importantly, the $A P A$ provided that ALJs could not be responsible to, or subject to supervision by, anyone performing investigative or prosecutorial functions for an agency. ${ }^{34}$ To do so, the $A P A$ required agencies to separate the prosecuting functions of an agency from its adjudicating functions. ${ }^{35} \quad$ Specifically, anyone who investigated or prosecuted a case could not supervise or direct those individuals who adjudicated the case. ${ }^{36}$ Additionally, those individuals who investigated or prosecuted could not be part of the decisionmaking process. ${ }^{37}$ Further, the $A P A$ limited some ex parte communications. ${ }^{38}$

The centerpiece of the $A P A$ reforms, however, involved a strengthening of the position and status of hearing examiners. ${ }^{39}$ The $A P A$ greatly improved the status of some, but not all, administrative judges by creating a new position, that of the ALJ

30 See Lubbers, supra note 27 at 111 ("Furthermore, the role of the presiding officer in an agency's decisional process was often unclear; many agencies would ignore the officer's decisions without giving reasons, and enter their own de novo decisions.").

31 John D. O'Reilly, Jr., "The Federal Administrative Court Proposal: An Examination of General Principles" (1937) 6 Fordham L Rev 365; See also Attorney General's Committee on Administrative Procedure - Majority and Minority Reports, (1941) 27 ABA J 91 at 93.

32 See Rich, supra note 24 at 246 ("Yet the hearing officers were not granted complete independence from the agencies, for the $A P A$ allowed them to be assigned exclusively to particular agencies.").

335 U.S.C. $\$ 551$ et. seq.

34 See 5 U.S.C. $\$ 554(\mathrm{~d})(2)$ (2009). Indeed, Congress created a unique system because of its concern about separating the adjudicatory function from other conflicting agency functions. In 1970 and 1977 respectively, Congress created the Occupational Safety and Health Review Commission [OSHRC] and the Federal Mine Safety and Health Review Commission [FMSHRC]. Both are independent, Executive Branch agencies located outside the Department of Labor. Importantly, they have adjudicative authority only. "OSHRC determines whether regulations promulgated and enforced by the Occupational Safety and Health Administration have been violated. FMSHRC adjudicates violations of standards promulgated and enforced by the Mine Safety and Health Administration." Robin J. Arzt, "Recommendations for a new Independent Adjudication Agency to Make the Final Administrative Adjudications of Social Security Act Benefits Claims" (2003) 23 Journal of the National Association of Administrative Law Judges 267 at 281. 5 U.S.C. $\$ 554(d)$.

Ibid.

37 Ibid. There were, however, some exceptions. The APA provides that "[t]his subsection does not apply... to the agency or a member or members of the body comprising the agency." 5 U.S.C. \$ 554(d)(2)(C). As a result, "a member or members of the body comprising the agency" could be involved in prosecutorial, investigatory, and adjudicatory functions. Ibid.

385 U.S.C. $\$ 554$ (d). Congress later amended the $A P A$ to add another section designed to address ex parte communications. 5 U.S.C. $\$ 557(\mathrm{~d})$.

39 William S. Jordan, III, “Chevron and hearing rights: An Unintended Combination, (2009) 61 Admin L Rev 249 at 270 citing Kenneth Culp Davis, Administrative Law (St. Paul, MN: West Publishing Company, 1951) at 309. 
(initially, the $A P A$ referred to ALJs as "hearing examiners"), ${ }^{40}$ and by giving ALJs protections designed to bolster their independence." In particular, ALJs were to be certified by the Office of Personnel Management [OPM] and were not subject to a probationary period. ${ }^{42}$ OPM was directed to determine the minimum experience needed to be an ALJ and to evaluate applicants for the position (by conducting interviews, administering a test of writing ability, evaluating the experience of applicants, and ranking eligible applicants). ${ }^{43}$ Despite these improvements, agencies retained control over the choice of who was actually selected from OPM's register and who was actually hired into ALJ positions. ${ }^{4}$ In other words, the agencies retained control over the selection of ALJs who worked for them, even if the pool of available candidates was shrunk and controlled by OPM.

Once hired, ALJs enjoyed increased job protections and independence vis-a-vis pre- $A P A$ hearing examiners. Although the $A P A$ did not grant ALJs the life tenure granted to Article III judges, ALJs could be removed only for cause or due to a reduction in workforce. ${ }^{45}$ In addition, the $A P A$ required that ALJs be assigned cases in rotation and that ALJs not perform duties inconsistent with their role as ALJs. ${ }^{46}$ Additionally, the APA required that ALJ compensation be determined based on length of service rather than based on performance evaluations. As the Supreme Court concluded, these changes made a significant difference in the status of ALJs:

There can be little doubt that the role of the modern federal hearing examiner or administrative law judge within this framework is "functionally comparable" to that of a judge. His powers are often, if not generally, comparable to those of a trial judge.... More importantly, the process of agency adjudication is currently structured so as to assure that the hearing examiner exercises his independent judgment on the evidence before him, free from pressures by the parties or other officials within the agency. ${ }^{47}$

40 Marvin H. Morse, “The Administrative Law Judge: A New Direction for the Corps?” (1983) 30 Fed B News \& J 398 at 401 n. 2 ("The $A P A$... initially referred to presiding officers as examiners, colloquially referred to as hearing examiners. The title was administratively standardized to Administrative Law Judge by the Civil Service Commission in August 1972. The ALJ title was ratified by the Act of March 27, 1978, Pub. L. No. 95-251, 92 Stat. 183.”). See also Paul R. Verkuil et al., "The Federal Administrative Judiciary" 1992 Administrative Conference of the United States 771, 798 (1992). In 1978, Congress amended the $A P A$ to official change the term from hearing examiners to administrative law judges. Pub. L. No. 95-251, 92 Stat. 183 (1978).

41 See also Rich, supra note 24 at 246. Congress, in its 1946 Administrative Procedure Act [APA] sought to establish a corps of federal hearing officers that were more independent of the agencies. Hearing officers were to be given career appointments and compensation was to be managed by the Office of Personnel Management. Yet the hearing officers were not granted complete independence from the agencies, for the $A P A$ allowed them to be assigned exclusively to particular agencies.

42 OPM has been "exclusively responsible for the initial examination, certification for selection, and compensation of ALJs." Lubbers, supra note 27 at 112.

43 Ibid.

44 Ibid.

455 U.S.C. $\$ 7521 ; 5$ C.F.R. $\$ 1201.131$ (2007).

$46 \quad 5$ U.S.C. $\$ 3105$ (2009); 5 C.F.R. $\ 930.212$ (2007).

47 Butz v. Economou, 438 U.S. 478, 513 (1978). 
As Michael Asimow and Jeffrey Lubbers have argued, ${ }^{48}$ the $A P A$ system is hardly perfect. There are difficulties with selection criteria, as well as with the inability of agencies to conduct performance evaluations. These concerns may be legitimate, but are beyond the scope of this article.

\section{DEPARTURES FROM THE ARTICLE III JUDICIAL MODEL}

Even though the $A P A$ significantly altered the status and work of administrative judges, the $A P A$ departed from the Article III judicial model in important respects. Critically, the $A P A$ did not convert all administrative judges into "ALJs." Indeed, the $A P A$ did not even require that all administrative adjudications be conducted by ALJs. "9 Rather, the $A P A$ required only that ALJs be used for "formal," as opposed to "informal," hearings. ${ }^{50}$ Today, informal adjudication is much more prevalent than formal adjudication as a consequence of the Supreme Court's decision in Florida East Coast Ry. v. United States ${ }^{51}$ (which created a presumption in favour of informality for rulemaking), and the lower courts' application of this principle to adjudication. ${ }^{52}$ As a result, many administrative judges continue to decide cases without the status of an ALJ.

Even when the $A P A$ (or the agency's governing statute) requires an agency to use an ALJ, the $A P A$ limits the ALJs' power. Specifically, the drafters of the $A P A$ chose not to give ALJs complete control over the cases they decided. Thus, if an agency wished, the agency was free to decide the case itself or to have the case heard by one or more members of the body comprising the agency. ${ }^{53}$ If the agency did not choose one of those two options, however, the $A P A$ did require the agency to have one or more ALJs appointed to preside at the taking of evidence. ${ }^{54}$ But, even when an ALJ heard a case, the $A P A$ did not require the agency to allow the ALJ to render the final decision in the case. ${ }^{55}$ The agency could command "either in specific cases or by general rule, the entire record to be certified to it for decision." "In other words, the agency could direct the ALJ to act as no more than an information gatherer.

See Michael Asimow and Jeffrey S. Lubbers, "The Merits of "Merits" Review: A Comparative Look at the Australian Administrative Appeals Tribunal” (2010) 28:2 Windsor YB Access Just, for a more detailed discussion of these issues ["The Merits of "Merits" Review"].

Chevron U.S.A., Inc. v. Natural Resources Defense Council, Inc., 467 U.S. 837 (1984).

50 Section 554 of the $A P A$ applies "in every case of adjudication required by statute to be determined on the record after opportunity for an agency hearing." 5 U.S.C. $\int 554$ (a). statute to trigger formal rulemaking).

52 Chemical Waste Mgm't, Inc. v. U.S. EPA, 873 F.2d 1477 (D.C. Cir. 1989) (holding that Chevron deference applies to an agency's decision regarding whether a formal rather than an informal adjudication was required by the enabling statute). But see Jordan, supra note 39, at 254 (arguing that the $A P A$ creates a presumption that formal adjudication should apply unless Congress clearly provides otherwise); Melissa M. Berry, "Beyond Chevron's Domain: Agency Interpretations of Statutory Procedural Provisions, (2007) 30 Seattle UL Rev 541 (arguing that Congress did not intend to delegate this decision to the agencies in light of concerns about agency self-interest and fairness); John F. Stanley, "The 'Magic Words' of $\$ 554$ : A New Test for Formal Adjudication Under the Administrative Procedure Act", Note, (2005) 56 Hastings LJ 1067 (suggesting that Skidmore deference would be a better deference standard for review of agency decisions regarding the formality of the procedure required by the $A P A)$.

535 U.S.C. $\int 554(\mathrm{a})$.

545 U.S.C. $\int 556(\mathrm{~b})$.

555 U.S.C. $₫ 557$.

$56 \quad 5$ U.S.C. $\int 557(b)$. 
Perhaps most importantly, although the ALJ's decision would become the agency's final decision if it were not appealed to the agency, the agency retained broad authority to review the ALJ's decision and to substitute its own judgment for that of the ALJ. ${ }^{57}$ The net effect was that administrative judges were "subservient to their agencies in the permanency of their decisions." ${ }^{58}$ Unlike Article III judges, who are immune from executive override (even Congress has limited authority to overrule their decisions retroactively), ALJs (at the agency's option) can be forced to play a minimal (advisory), even no, role in adjudication.

Hence, although the $A P A$ improved the administrative law judge's independence and impartiality ${ }^{59}$ in many ways, the reforms were not intended to and did not give administrative judges the status of Article III judges, nor completely shift the nature of the administrative adjudicative process.

\section{ALTERNATIVES TO THE CURRENT SYSTEM}

For decades, commentators have suggested alternative models for administrative adjudication. Of course, any suggested reform must deal with fundamental tradeoffs. In other words, even if some might prefer to make administrative adjudication more independent and impartial, the question is whether and, if so to what extent, executive agencies should be allowed to ensure that adjudicative decisions conform to the policy and political concerns of agency administrators. A number of suggestions have been made for how to resolve this fundamental conflict. Below are a few options that other scholars have suggested along with a few new ideas.

\section{A. Expanding APA Protections to Administrative Judges}

One solution to this problem would be to extend ALJ-like protections to more administrative judges. It is difficult to deny that the $A P A$ has brought significant improvements to the status of those administrative judges denominated "ALJs." However, it is also difficult to deny the fact that the $A P A$ left a variety of administrative judges without the benefit of ALJ status. As we noted earlier, informal adjudications are much more common today than perhaps was originally envisioned by the $A P A$ drafters, and therefore many of the decisionmakers in these informal adjudications function with fewer protections than ALJs. So, one possibility would be to require that more administrative adjudications be conducted as "formal" (rather than "informal") proceedings." If that were done, then the $A P A$ would require agencies to make greater use of ALJs (with, of course, greater protections than the administrative judges currently deciding their cases).

$57 \quad$ Ibid.

58 Moliterno, supra note 21, at 1224.

59 "Impartiality as a judicial trait is often confused with independence. Impartiality is about fair-minded, neutral decisionmaking. Independence is created primarily by structural aspects of government. Impartiality is created primarily by the structure of the dispute resolution process. All judges are in systems that foster impartiality; some judges are in structures that foster independence." Moliterno, supra note 21 , at 1199 .

60 This topic is beyond the bounds of this paper; however, for an excellent discussion of this issue, see Jordan, supra note 39 at 254 (arguing that formal adjudication should apply unless Congress clearly provides otherwise in the enabling statute); Michael Asimow, "The Spreading Umbrella: Extending the APA's Adjudication Provisions to all Evidentiary Hearings Required by Statute” (2004) 56 Admin L Rev 1003 (suggesting that some $A P A$ protections, e.g. ex parte prohibitions, should be accorded to adjudications that while not formal under the $A P A$ distinction are very procedurally prescribed due to statutory requirements). Accord, Berry, supra note 52, at 579-80 (suggesting that Congress did not intend for agencies to choose whether formal or informal hearings were appropriate). 
The downside to this approach is that it may not be wise to unduly formalize the administrative process. Formal procedures are more involved and burdensome, and require administrative agencies to provide greater process to litigants. ${ }^{61}$ However, more is not always better, and an enhanced process is not always preferable to an informal process. For example, administrative agencies frequently conduct so-called "due process" hearings under the United States Supreme Court's decision in Goldberg v. Kelly. ${ }^{62}$ Under that decision, courts are required to grant hearings in a variety of contexts, not by virtue of a congressional mandate, but rather because a hearing is required under one of the due process clauses. ${ }^{63}$ Even though a due process hearing might be required in a given case, the Court does not require that the process be "formal" in the $A P A$ sense. On the contrary, the Court has recognized that it is often permissible to allow agencies to utilize less involved procedures. Indeed, in the Court's decision in Matthews $v$. Eldridge, ${ }^{64}$ the Court suggested that the amount of process required in a given case should depend upon a balancing of the need for enhanced procedures against the burden that the additional procedures would impose on the administrative process. A shift to a widespread use of formal hearing procedures would necessarily impose a much greater burden on the agencies involved and might discourage agencies from granting hearings in more cases (and, correspondingly, may discourage courts from ordering more hearings).

\section{B. The Central Panel and Federal Administrative Court Systems}

Denouncing the present system as one that hinders independence, many ALJs enthusiastically support the option of creating a central panel of administrative law judges (essentially, an independent administrative judiciary managed by a central administrator). ${ }^{65}$ ALJs were not the first to propose this option. As noted earlier, prior to the enactment of the $A P A$, some commentators argued for creation of a central panel system. ${ }^{6}$ During enactment of the $A P A$, the idea was revived and discussed further. $^{67}$ A variation of the central panel option would be to establish a single, federal administrative court. The judges on such a court would hear only administrative cases. ${ }^{68}$

As noted, when Congress enacted the $A P A$, it specifically rejected both the single panel and administrative court options, choosing instead to have ALJs work within the agencies for which they adjudicate and to have ALJs report to non-ALJs within those agencies. As a result, instead "of establishing the examiners as an independent

See generally procedures in 5 U.S.C. $\iint 556 \& 557$ (2009).

397 U.S. 254 (1970)

63 The Constitution contains two due process clauses; one located in the Fifth Amendment and one located in the Fourth Amendment. U.S. Constit. amend. V \& XIV, $₫ 1$.

64424 U.S. 319 (1976).

65 Moliterno, supra note 21, at 1227 (citing Victor W. Palmer, "The Administrative Procedure Act: After 40 Years, Still Searching for Independence” (1987) Judges' Journal at 34, 39.).

66 See John D. O'Reilly, Jr., "The Federal Administrative Court Proposal: An Examination of General Principles" 6 Fordham L Rev 365 (1937); See also Attorney General's Committee on Administrative Procedure - Majority and Minority Reports, (1941)27 ABA J 91 at 93.

67 Moliterno, supra note 21, at 1227 (citing Palmer, supra note 65, at 37 and Ralph F. Fuchs, "The Hearing Examiner Fiasco Under the Administrative Procedure Act” (1950) 63 Harv L Rev 737 at 739 ("[C]orps of highly responsible hearing officers [was] originally put forward by the Attorney General's Committee.”).

68 While the two are similar, a federal administrative court would actually hear cases. In contrast, a central panel would manage the ALJs and assign them to hear cases within agencies (and within the agency judicial structures). 
corps, as recommended in the minority report, the responsibility for protecting critical elements in the employment of hearing examiners was entrusted to the Civil Service Commission." ${ }^{\prime \prime}$

Despite Congress's rejection of the central panel option, support for that idea has never entirely disappeared. In 1983, “[t]he Judicial Administration Division passed a resolution ... favoring the passage of legislation to establish federal administrative law judges as an independent corps." ${ }^{\text {T0 }}$ Some scholars have made similar recommendations, ${ }^{\text {"1 }}$ and central panels have been used successfully in a number of states. $^{12}$

There are a number of advantages to the central panel and federal administrative court options. First, both systems would increase efficiency by allowing for centralized organization and management of ALJ offices. Rather than having lots of judges scattered among a variety of agencies, there would be one large judicial structure. Second, impartiality, or at least the appearance of impartiality, would increase as administrative judges would be located outside of the agencies for which they decide cases. Under the current system, litigants (especially pro se litigants) may be uncertain about the impartiality of administrative judges who work for the agency that the litigants are appearing before. ${ }^{73}$

One primary concern-judicial independence-would likely increase as well. As Justice Scalia has recognized, the "problem of improper influence would ... be solved by implementing proposals for establishment of a unified ALJ corps, headed by an independent administrator." ${ }^{\text {?/4 }}$ At least one commentator agreed with Justice Scalia when he stated that the "basic purpose of the central panel system is to give ALJs a certain amount of independence from the agencies over whose proceedings they preside...." ${ }^{75}$ As these comments suggest, judicial independence is less achievable when administrative judges are employees of the agencies for which they decide cases, and a federal administrative court separates litigants from their agencies.

But proposals to create either a central panel system or a federal administrative tribunal are not without disadvantages as well. Indeed, in a 1992 study prepared by the Administrative Conference of the United States, the idea of a central panel system

69 Palmer, supra note 65 at 37.

70 Ibid at 39

71 See e.g. Hoffman \& Cihlar, supra note 13, at 878; See also Jim Rossi, "Overcoming Parochialism: State Administrative Procedure and Institutional Design" (2001) 53 Admin L Rev 551 at 568 ("[T] he central panel promotes independence ... [b]y removing ALJs from the managerial auspices of the agencies whose matters they adjudicate ....").

72 Palmer, supra note 65 at 39. See e.g. Ariz. Rev. Stat. Ann. \ 41-1092.01; Ga. Code Ann. \50-13-40; Md. Code Ann., State Gov't \ 9-1602 (LexisNexis); Tex. Gov't Code Ann. \2003.021 (Vernon); Yvette N. Diamond, “OAH - What's It All About?" Maryland Bar Journal Jan. /Feb. 2006, at 4, 6 (identifying the Office of Administrative Hearings in Maryland as "a centralized panel of ALJs in a separate and independent agency under the executive branch of the Maryland state government"). See generally James F. Flanagan, "An Update on Developments in Central Panels and ALJ Final Order Authority" (2005) 38 Ind L Rev 401

73 The system might seem strange to the uninitiated for any number of reasons. First, one of the litigants in front of the administrative judge is often the judge's employer. Second, opposing counsel may be the administrative judge's co-worker. Third, the agency's experts may also be co-workers of the judge. Finally, the administrator of one of the litigants will control the judge's budget. Moliterno, supra note 21 at 1195 .

74 Antonin Scalia, "The ALJ Fiasco—a Repris" (1979) 47 U Chicago L Rev 57 at 79.

75 Allen C. Hoberg, “Administrative Hearings: State Central Panels in the 1990s” (1994) 46 Admin L $\operatorname{Rev} 75$ at 76$)$. 
was rejected. ${ }^{76}$ Moreover, despite the language quoted above, Justice Scalia is more opposed to the option than in favour of it." Why? Some scholars question whether administrative judges need or require greater independence. The Constitution granted Article III judges life tenure in order to ensure that they could function independently of the executive and legislative branches and, therefore, could provide a check on the powers of those branches. ${ }^{78}$ Administrative judges do not perform that same function." As one commentator noted, "administrative judges are meant to make impartial decisions, but not to be independent... in the sense of that word that connotes the usual judge's attribute. They were meant to be impartial decisionmakers and advancers of agency policy, not independent ones." ${ }^{\text {"so }}$ To some degree, the central panel and federal administrative court options attempt to transform ALJs into Article III judges who are free to police the executive branch and either advance or even hinder executive policies. " "П] nsofar as [these options] further the rupture of the administrative judiciary from the executive branch, they are an undesirable development in the law." ${ }^{32}$

Another disadvantage of these options would be that some regulatory schemes are highly specialized, and ALJs may need special expertise to adjudicate effectively under those schemes. In other words, it is not clear that an ALJ could hear an Environmental Protection Agency case one day, a Nuclear Regulatory Commission case the next, and a Securities and Exchange Commission case on the third day and rule competently in each. The current system allows ALJs to work within their particular areas of expertise. Having said that, we note that there is no similar concern with Article III judges exercising expertise in a variety of regulatory areas. For example, the D.C. Circuit regularly hears all kinds of administrative law cases, yet it has no special expertise in any of the underlying substantive areas. ${ }^{83}$

76

Verkuil et al., supra note 40

77 He argued that the central panel would only be valuable if it did not alter the role of the administrative judiciary. Scalia, supra note 74 at 79 .

78 Moliterno, supra note 21 at 1215 ("Congress intended that the provisions of the $[A P A]$ secure a certain amount of independence for administrative judges as a means toward impartiality of decisionmaking, whereas for Article III judges it is a means both for impartiality and the maintenance of a separate branch of government.").

79 Ibid at 1191.

$80 \quad$ Ibid at 1210-11, 1232 ("Administrative judges are not meant to be checks on out-of-bounds exercises of legislative and executive power.”).

$81 \quad$ Ibid at 1230 .

82 Ibid at 1230

83 Chief Justice John Roberts talked about the expertise of the D.C. Circuit before he joined the Supreme Court:

The first decision to give administrative jurisdiction to the D.C. Circuit in 1870, as well as a handful of similar decisions in the early twentieth century, became prototypes for a succession of legislative grants of authority to re-view decisions of the FCC, the Federal Power Agency (later FERC), the EPA, the NLRB, the FTC, and the FAA. Whatever combination of letters you can put together, it is likely that jurisdiction to review that agency's decision is vested in the D.C. Circuit. Even when the jurisdiction is concurrent, as it often is-decisions of the NLRB, for example, can be reviewed in the D.C. Circuit, in the circuit where the petitioner resides, or in the circuit where the events giving rise to the matter took placelawyers frequently prefer to litigate in the D.C. Circuit because there is a far more extensive body of administrative law developed there than in other circuits. John G. Roberts, Jr., "What Makes the D.C. Circuit Different? A Historical View” (2006) 92 Va L Rev 375 at 388-89. 
There remains a more fundamental problem with the central panel option, which might not be true of the federal administrative court option: the agency would still be the final decisionmaker under the $A P A$ and could freely substitute its judgment for that of the ALJ. If the agency retains the final say in the case, there is perhaps less reason to be concerned about the need for administrative judges to function independently since they are simply rendering the initial decision. Of course, the $A P A$ could be altered to vest final decisionmaking authority in administrative judges rather than in the head of the agency. However, if that change were made, administrative judges would assume a much greater policy role within the agency than they have currently. As they interpret and apply regulatory provisions, they would assume greater responsibility for "saying what those provisions mean," and, therefore, give content to the scheme itself. As a result, the agency would have less control over its regulatory scheme and its regulatory law.

In addition, establishing a federal administrative court, in particular, would likely be very expensive and require a complete change to the current system. Thus, while the central panel and federal administrative court options have some advantages, ultimately, neither approach provides a panacea to the deficiencies of the present system.

\section{Establishing More Article I Courts}

Another option would be for Congress to create more Article I courts. Article I, or legislative, courts are created by Congress pursuant to its Article I powers, ${ }^{84}$ and Congress has created such courts to review the final administrative decisions of some agencies. Two such examples include the Tax Court, ${ }^{85}$ which hears appeals from Internal Revenue System's tax decisions, and the U.S. Court of Appeals for Veterans Claims, which hears appeals of benefits decisions made by the Board of Veterans Appeals. ${ }^{86}$ These courts take many forms and vary in their level of independence from the executive and legislative branches. For example, judicial protection is generally limited. While Article III judges enjoy lifetime tenure and protected salaries, Article I judges are not subject to these protections. Yet most, if not all, Article I courts are both separately located from their agencies and have the power to issue final decisions.

84 The legitimacy of Article I courts has been controversial and subject to challenge. See e.g. American Ins. Co. v. 356 Bales of Cotton, 1 Pet. 511 (1828) (holding that a territorial court established under Article I of the Constitution could not exercise federal judicial power because the judges did not have lifetime tenure; therefore, the law that placed admiralty cases within their jurisdiction was unconstitutional). But that battle appears to be over. The Supreme Court has held that Article I courts are constitutional; however, their power is limited. When there is an allegation regarding the potential deprivation of an interest in life, liberty, or property, Article I court decisions must be subject to review by an Article III court. Northern Pipeline Co. v. Marathon Pipe Line Co., 458 U.S. 50 (1982).

85 The Tax Court was established to address both independence and impartiality: $\Pi$ t would never be possible to give to the taxpayer the fair and independent review to which he is of right entitled as long as the appellate tribunal is directly under, and its recommendations subject to the approval of, the officer whose duty it is to administer the law and collect the tax. As long as the appellate tribunal is part and parcel of the collecting machinery it can hardly maintain the attitude essential to a judicial tribunal. Report of Tax Simplification Board: Hearing on H.R. Rep. No. 68-103, at 4 (1st Sess. 1923).

86 The U.S. Court of Appeals for Veterans Claims was created by Congress in 1988 to exercise exclusive jurisdiction over the decisions of the Board of Veterans' Appeals on the motion of claimants. The Court has a very heavy caseload. The U.S. Court of Appeals for the Federal Circuit has limited appellate review. 
There are advantages to a decision to create more such courts. First, judicial independence and impartiality would both increase; as with central panels and the federal administrative law court, administrative judges would be housed outside of the agencies for which they work and would not be subject to agency oversight. Additionally, Article I judges would be the final agency decisionmakers. While their decisions are appealable to Article III courts, agencies would have no ability to overrule the Article I court's decision. Importantly, however, unlike these other options, expertise would not be sacrificed; Article I judges would have expertise within their assigned areas and would likely make better decisions in areas that are legally complex and that involve highly technical facts.

But the potential costs in establishing many more Article I courts would likely be staggering, likely even more so than establishing one, federal administrative court system. Another potential disadvantage would be that agencies would no longer be able to formulate policy via adjudication; ${ }^{87}$ rather, all policy would have to be made via legislative and non-legislative rulemaking. ${ }^{88}$ Under current case law, agencies have discretion about whether to articulate new policy legislatively or adjudicatively. ${ }^{89}$ While some commentators criticized this legal development, ${ }^{90}$ the choice has remained the agency's for more than sixty years. Certainly, agencies should strive to articulate broadly applicable policy via rulemaking rather than adjudication, but choice furthers flexibility. ${ }^{91} \quad$ Even if agencies wanted to articulate all policy by using rulemaking procedures, it would be impossible for them to do so; case-by-case development is a necessary and inevitable part of administrative policymaking. ${ }^{92}$ Hence, any change to the adjudicative structure that would effectively require agencies to articulate policy exclusively via legislative procedures would be undesirable.

87 S.E.C. v. Chenery Corp., 332 U.S. 194 (1947); See generally, Russell L. Weaver \& Linda D. Jellum, "Chenery II and the Development of Federal Administrative Law" (2006) 58 Admin L Rev 815 (arguing that agencies should have the choice of whether to develop law via rulemaking or adjudication).

88 Arzt, supra note 34 at 280-81 ("When an agency no longer formulates policy through its adjudication function but does so only through rulemaking ... supervision of the appellate administrative adjudicators and review of their decisions by policy-making political appointees has no reason to continue. At that point, there is no reason to keep the adjudicatory function within the agency."). S.E.C. v. Chenery Corp., supra note 87.

90 See e.g. Arthur E. Bonfield, "The Federal APA and State Administrative Law" 72 Va L Rev 297, 325 34 (1986) (suggesting that states should choose rulemaking over formal adjudication); Cornelius J. Peck, "The Atrophied Rule-Making Powers of the National Labor Relations Board" (1961) 70 Yale LJ 729 at 730 (criticizing the National Labor Relations Board [NLRB] for not exercising its rulemaking powers enough); Glen O. Robinson, "The Making of Administrative Policy: Another Look at Rulemaking and Adjudication and Administrative Procedure Reform” (1970) 118 U Pa L Rev 485 at 486 (recognizing broad concern that agencies engage in adjudication at the expense of rulemaking); David L. Shapiro, "The Choice of Rulemaking or Adjudication in the Development of Administrative Policy" (1965) 78 Harv L Rev 921 at 922 (questioning agencies' choice of weapons in making policy); Peter L. Strauss, "Rules, Adjudications, and Other Sources of Law in an Executive Department: Reflections on the Interior Department's Administration of the Mining Law” (1974) 74 Colum L Rev 1231 at 1233 (reviewing the Department of Interior's choices between rulemaking and adjudication in implementing the General Mining Law); Russell L. Weaver, "Chenery II: A Forty Year Retrospective" (1988) 40 Admin L Rev 161 at 161; J. Skelly Wright, "The Courts and the Rulemaking Process: The Limits of Judicial Review" (1974) 59 Cornell L Rev 375 at 376 (suggesting that agencies must engage in rulemaking and not adjudication when Congress has adopted a regulatory solution).

91 For a more thorough discussion of this topic, See generally, Weaver \& Jellum, supra note 87 (arguing that Chenery II was rightly decided).

92 Ibid at 826-27. 
Finally, the more the new system looks like the old Article III system, the more likely the new system will become more adversarial, more expensive, and more protracted for litigants and agencies.

Professors Michael Asimow and Jeffrey Lubbers have argued for a slightly different formulation of this idea." They suggest creation of "a single adjudicating tribunal, referred to as a Benefits Review Tribunal [BRT]" which would handle benefits review cases from Social Security, the Veterans Administration, and perhaps benefits programs administered by the Department of Labor. Their proposed system finds its roots in the Australian Administrative Appeals Tribunal. In the abstract, the proposal might draw strong support from ALJs because it places them outside of the agencies for which they adjudicate cases and helps ensure their independence. However, ALJs would be subject to the governing agencies "hard" law and "soft" law. In other words, at least in theory, the ALJs in this new tribunal would not be expected or allowed to "make law." We suspect that ALJs will strongly oppose the proposal because professors Asimow and Lubbers hope that the new tribunal would exercise greater control over ALJ hiring, supervision, compensation, case-assignment, evaluation, and discharge. For example, they suggest a peer review procedure for evaluating work product, and many ALJs object to the notion of performance reviews. In addition, we are not certain that this new tribunal will be able to successfully decide benefits cases without venturing into the arena of policy creation.

\section{Changing the $A P A$ Process}

Another possibility would be to alter the $A P A$ review process to prohibit agencies from reviewing the decisions of administrative judges. Currently, the head of an administrative agency serves as the court of last resort for the administrative process and has the power to issue the agency's final decision. ${ }^{94}$ Hence, the agency reviews all ALJ findings de novo.

The current system could be altered in a variety of ways. First, Congress could amend the $A P A$ and mandate that the head of the agency be more deferential to the administrative judge's decision. For example, Congress might provide that the agency head can only review the administrative judge's findings for "clear error" or for an "abuse of discretion." This higher standard could apply to all ALJ findings or just to a subset of findings such as findings of fact. Currently, the agency head should give some weight to credibility findings based on demeanour, but may review all other findings of fact de novo. ${ }^{95}$ In contrast, Article III courts can set aside lower court findings of fact only when those findings are "clearly erroneous." ${ }^{. \%}$ A higher standard of review for factual findings would give ALJs greater independence and authority. If the standard for reviewing agency policy and legal decisions remained the same -de novo- then the agency would retain its ability to formulate policy and interpret statutes while ALJs would play a role more like that of a trial judge. The disadvantages of this change are not readily apparent. But the change would be so minor, it may not be worth the effort to amend the $A P A$.

A second approach would be to provide for finality of ALJ (and, for that matter, administrative judge) decisions. This approach is popular among those who support

\footnotetext{
93 See Asimow \& Lubbers, supra note 48.

945 U.S.C. $\$ 557$ (b) (2009) ("On appeal from or review of the initial decision, the agency has all the powers which it would have in making the initial decision....").

95 Penasquitos Village v. Nat. Labor Relations Bd., 565 F.2d 1074 (9th Cir. 1977).

96 Fed. Rule Civ. Pro. 52(a)(6).
} 
the central panel system, which usually includes the idea of finality." While finality is not an essential attribute of a central panel system, the model act creating a state central hearing agency specifically provides that administrative judges can issue either initial or final decisions. ${ }^{98}$ An advantage of this option would be that administrative judges could play a much stronger, more independent, and final role in the adjudicative process. Indeed, the decisions of administrative judges (and ALJs) would become the final decision of the agency and would not be subject to reversal by the agency litigant.

The disadvantage of this second approach would be that agencies heads, who are both politically accountable and often experts in the field, would lose control over their agencies' decisions, which can create agency policy. Giving ALJs finality would transform administrative judges into something like Article III judges, meaning that ALJs would be able to render judgments on the actions of the executive branch without any review from that branch. "That is not the role for which administrative judges were created."’9 As one commentator noted,

Administrative judges, unlike Article III judges, exist in order to further the policies of the executive branch, specifically the agency for which they judge, through the impartial adjudication of disputes. Allowing administrative judges final authority over policy and perhaps even over fact findings, however, would thwart that end.... Administrative judges would be rendered c $A P A b l e$ of deciding cases in contradiction with the stated policies of the executive branch. ${ }^{100}$

Additionally, inconsistencies could be created between an agency's articulated policies and ensuing adjudications. This might create uncertainty in the law, result in loss of political accountability, and nullify agency experience in formulating policy under its statutory mandate. ${ }^{101}$ Adjudicative policymaking is inherent in an effective regulatory regime.

An additional problem might result from a lack of flexibility for policy-making. As we mentioned earlier, agencies can choose to articulate regulatory policy either legislatively or adjudicatively. ${ }^{102}$ At times, case-by-case policy development is the best choice. ${ }^{103}$ To the extent that this change could preclude agencies from articulating policy via adjudication, then it is less than ideal.

\section{CONCLUSION}

97 Moliterno, supra note 21 at 1231.

98 Christopher B. McNeil, "The Model Act Creating a State Central Hearing Agency: Promises, Practical Problems, and a Proposal for Change” (2001) 53 Admin L Rev 475 at 497.

99 Moliterno, supra note 21, at 1231 (quoting Flanagan, supra note 13, at 1388. "Another argument made in support of ALJ finality is that it protects ALJ independence. The argument that ALJ finality enhances ALJ independence is true, in the sense that final order authority does make the ALJ completely independent of the agency. The argument, however, confuses the means with the end. ALJ independence is an important factor in administrative adjudication when it eliminates improper agency influence, but certainly, it is not the purpose of agency adjudication to make ALJs independent.”). Ibid. (footnotes omitted).

100 Ibid at 1226.

101 Ibid at 1227.

102 S.E.C. v. Chenery Corp., supra note 87.

103 Weaver \& Jellum, supra note 87 at 826-27. 
Is there a better way to structure the modern administrative adjudicatory system? Probably, but the way is not clear. While, the APA's ALJ protections could be expanded to include more administrative judges, it would certainly be unrealistic, and likely counter-productive, to elevate all administrative judges to ALJ status. Cases such as Goldberg v. Kelly ${ }^{104}$ and Goss v. Lopez $z^{105}$ greatly expanded the number of hearings agencies must now provide. With more formality comes added expense and delay, for both sides. As the Supreme Court made clear in Mathews v. Eldridge, ${ }^{106}$ the interest of litigants in more procedure and formality must be balanced against the agency's interest in quicker, more streamlined, and less expensive procedures. Yet, the current system favors expediency over judicial independence. Including more administrative judges within the umbrella of protection might tilt the balance back.

Additionally, altering the deference standard would similarly increase judicial independence in a relatively small way, but at little cost to the agency. So long as the agency remains free to decide policy issues de novo, perhaps even legal issues, the agency retains its ability to formulate policy. But even combined, these two changes are likely only to have a minimal impact on improving judicial independence. And while creating more Article I courts would increase independence more dramatically, this option would be unduly expensive and unlikely to garner much support in Congress during these tough economic times. While an Article I court could be structured like the Australian Administrative Appeals Tribunal, as professors Asimow and Lubbers suggest, that proposal is likely to draw intense ALJ opposition.

The remaining options present a more fundamental question: whether the administrative adjudicative structure should be fundamentally reshaped. These proposals (the central panel system, the notion of ALJ finality, and the idea for an administrative court) all contemplate that administrative judges would play a much greater role in shaping and formulating agency policy. Through their decisions, administrative judges would construe and apply regulatory provisions. And at least some of the proposals contemplate that there should be no review of these decisions within agencies. Long ago, Congress decided that this loss of control would be undesirable. The choice remains a reasonable one.

Thus, while it might be time to reform our current administrative adjudicatory system, it is not clear which, if any of these options, would best balance the competing interests and further the administrative agenda.

104397 U.S. 254 (1970) (holding that the recipient of certain government benefits (welfare) must receive a hearing before they can be deprived of such benefits).

105419 U.S. 565 (1975) (holding that a public school must conduct a hearing before suspending a student).

106424 U.S. 319 (1976). 